\title{
INVESTIGATION OF BIOLOGICAL ACTIVITIES AND SECONDARY METABOLITES OF HYDNUM REPANDUM ACETONE EXTRACT
}

\author{
JOVANA TUBIĆ ${ }^{1}$, DARKO GRUJIČIĆ ${ }^{1}$, MARINA RADOVIĆ JAKOVLJEVIĆ ${ }^{1}$, BRANISLAV \\ RANKOVIĆ $^{1}$, MARIJANA KOSANIĆ ${ }^{1}$, TATJANA STANOJKOVIĆ ${ }^{2}$, ANDRIJA ĆIRIĆ ${ }^{1}$, \\ OLIVERA MILOŠEVIĆ-DJORDJEVIĆ ${ }^{1,3 *}$
}

${ }^{1}$ University of Kragujevac, Faculty of Science, 34000 Kragujevac, Serbia
${ }^{2}$ Institute of Oncology and Radiology of Serbia, 11000 Belgrade, Serbia
${ }^{3}$ University of Kragujevac, Faculty of Medical Sciences, 34000 Kragujevac, Serbia

*corresponding author: olivera@kg.ac.rs

Manuscript received: May 2018

\begin{abstract}
This study aimed to evaluate the biological activities and polyphenolic contents of the acetone extract of $H$. repandum mushroom. Polyphenolic compounds were evaluated by high-performance liquid chromatography (HPLC). The antioxidant activity was assessed by radical scavenging activity assays and reducing power. The antimicrobial activity was established based on the values of the minimum inhibitory concentration (MIC) using microdilution method. Cytotoxic activity was determined by 3-4,5-dimethylthiazol-2-yl-2,5-diphenyltetrazolium bromide (MTT). The genotoxic and antimutagenic activities were tested using cytokinesis block micronucleus (CBMN) assay on human peripheral blood lymphocytes in vitro. Among the determined polyphenolic compounds, ferulic acid and quercetin were mostly found. The extract showed high free radical scavenging activity, while the reducing power was less emphasized and concentration-dependent. The MIC fluctuated in a range of $0.009-10 \mathrm{mg} / \mathrm{mL}$. The cytotoxic activity (based on $\mathrm{IC}_{50}$ ) ranged from 116.5 to $158.33 \mu \mathrm{g} / \mathrm{mL}$, when HeLa cells were the most sensitive. The highest tested concentrations of the extract showed significant genotoxic activity, while against mitomycin $\mathrm{C}$, the extract caused protective activity. The results indicated that $H$. repandum acetone extract contained secondary metabolites which showed biological activities such as antioxidant, antimicrobial, cytotoxic, genotoxic and protective against chemotherapeutics, indicating that their inclusion in nutrition could be of great importance in the prevention and treatment of various pathological conditions.
\end{abstract}

\section{Rezumat}

Acest studiu a urmărit evaluarea activităților biologice și conținutul polifenolic al extractului acetonic din ciuperci din specia H. repandum. Compușii polifenolici au fost evaluați prin cromatografie de lichide de înaltă performanță (HPLC). Activitatea antioxidantă a fost evaluată prin testele specifice. Activitatea antimicrobiană a fost stabilită pe baza valorilor concentrației inhibitorii minime (MIC) utilizând metoda microdiluției. Activitatea citotoxică a fost determinată cu ajutorul bromurii de 3 4,5-dimetiltiazol-2-il-2,5-difeniltetrazoliu (MTT). Activitățile genotoxice și antimutagene au fost testate in vitro pe limfocite din sânge periferic. Printre compuşii polifenolici determinați s-au regăsit predominant acid ferulic și quercetină. Extractul a demonstrat o activitate mai puternică de neutralizarea a radicalilor liberi. MIC a fluctuat în intervalul $0,009-10 \mathrm{mg} / \mathrm{mL}$. Activitatea citotoxică (pe baza IC50) a variat de la 116,5 până la $158,33 \mu \mathrm{g} / \mathrm{mL}$. Cele mai mari concentrații testate ale extractului au prezentat o activitate genotoxică semnificativă, în timp ce extractul de mitomicină C a prezentat o activitate protectoare. Rezultatele au arătat că extractul acetonic al $H$. repandum conține metaboliți secundari care au prezentat activități biologice antioxidante, antimicrobiene, citotoxice, genotoxice și protectoare împotriva chimioterapicelor, indicând faptul că includerea lor în nutriție ar putea avea o mare importanță în prevenirea și tratamentul diferitelor afecțiuni patologice.

Keywords: Hydnum repandum, antioxidant activity, antimicrobial activity, cytotoxic activity, genotoxic, antimutagenic activity

\section{Introduction}

Ever since the time of ancient civilizations, such as China, Japan, Europe, Mesoamerica and Africa, the medicinal properties of mushrooms have been used for the benefit of humans as food and medicine [1]. Moreover, in the recent years, the interest in the consumption of mushrooms has increased because of their nutritional composition. In addition to that, mushrooms are a significant source of natural biologically-active substances [2].

Mushrooms contain different secondary metabolites such as polyphenols, peptides, polysaccharides, vitamins, iron, zinc, sodium, minerals, terpenes, etc., with various biological activities [3]. Polyphenols are the widest group of bioactive substances, composed of phenolic acids, flavonoids, hydroxybenzoic acids, lignans, tannins, stilbenes and oxidized polyphenols, obtained from fruit bodies and the mycelium [4].

Hydnum repandum L. (popularly known as sweet tooth or wood hedgehog) is an edible and medicinal mushroom belonging to the Hydnaceae family [5]. Studies have confirmed that $H$. repandum possesses antioxidant [6] and antimicrobial [7] activities. 
FARMACIA, 2019, Vol. 67, 1

Repandiol isolated from $H$. repandum showed potent cytotoxic activity against various cancer cells [8].

Available literature contains very few data about the biological activities of this species. Thus, the aim of this study was to determine the polyphenolic compounds, the antioxidant, antimicrobial, cytotoxic, genotoxic and antimutagenic activities of the mushroom $H$. repandum acetone extract.

\section{Materials and Methods}

Collection and identification of the fungal sample The fungal sample of $H$. repandum was collected in Kragujevac, Serbia, in September in 2015. The demonstration sample is preserved in the facilities of the Department of Biology and Ecology of Kragujevac, Faculty of Science. The identification of the mushroom was conducted using standard methods [5].

Preparation of the extract

Finely dry ground thalli of the examined mushrooms were extracted with acetone in a Soxhlet extractor. The extract was filtered and then concentrated under reduced pressure in a rotary evaporator. The dry extract was stored at $-18^{\circ} \mathrm{C}$ until it was used in the tests. The extract was dissolved in 5\% dimethyl sulphoxide (DMSO) for the experiments. DMSO was dissolved in sterile distilled water to the desired concentration. The final concentration of DMSO solvent never exceeded $0.5 \%$ [9].

High performance liquid chromatography (HPLC) Chromatographic analysis was performed using a Shimadzu HPLC system (Shimadzu, Duisburg, Germany), consisting of a G1312A binary pump, a $7725 \mathrm{i}$ manual injector and a G1379A degasser. Separations of the analyses were achieved on a Luna C18 reversed - phase column $(250 \mathrm{~mm} \times 4.6 \mathrm{~mm}$ I.D., $5 \mu \mathrm{m}$, Phenomenex) connected with an Analytical KJ0-4282 C18 guard cartridge system for HPLC (Phenomenex, Torrance, CA, USA). The mobile phase consisted of acetonitrile (A) and $0.1 \%$ formic acid aqueous solution (B) using the following gradient elution program for separation: 0-5 min, 5\% (A); 5-30 min, 5-60\% (A); 30$32 \mathrm{~min}, 60-90 \%$ (A); 32-35 min, 90\% (A), 35$36 \mathrm{~min}, 90-5 \%$ (A); 36-40 min, 5\% (A). The column temperature was maintained at $30^{\circ} \mathrm{C}$, the flow rate was $1.0 \mathrm{~mL} / \mathrm{min}$ and the injection volume was $20 \mu \mathrm{L}$. The developed HPLC-DAD method was subsequently applied for the analysis of polyphenolic compounds in a sample of mushroom. Determining the antioxidant activity

DPPH radical scavenging activity

The DPPH (2,2-diphenyl-1-picrylhydrazil) radical scavenging capacity of the extract was evaluated according to a method previously used by some other authors [10], but it was modified in its details. Two milliliters of methanolic solution of DPPH radical in the concentration of $0.05 \mathrm{mg} / \mathrm{mL}$ and 1
$\mathrm{mL}$ of the test sample $(62.5,125,250,500$ and $1000 \mu \mathrm{g} / \mathrm{mL}$ ) were placed in cuvettes. The mixture was shaken and allowed to stand at room temperature for $30 \mathrm{~min}$. DPPH solution is initially violet in color which fades when antioxidants donate hydrogen. The change in color is monitored spectrophotometrically (Bibby Scientific Limited, Stone, UK) at $517 \mathrm{~nm}$ against methanol as blank. Ascorbic acid was used as a positive control. The DPPH radical concentration was calculated using the following equation: DPPH scavenging ability $(\%)=[(A 0-A 1) / A 0] \times 100$, where A0 is the absorbance of the negative control $(2 \mathrm{~mL}$ of methanol solution of DPPH radical $+1 \mathrm{~mL}$ of $5 \%$ DMSO) and A1 is the absorbance of reaction mixture or standard. For both extract and ascorbic acid, the $\mathrm{IC}_{50}$ values (the concentration required for $50 \%$ inhibition of DPPH radical) were determined. Superoxide anion radical scavenging activity The superoxide anion radical scavenging activity of the sample was detected according to the method of Nishimiki et al. [11] Briefly, $0.1 \mathrm{~mL}$ of test sample $(62.5,125,250,500$ and $1000 \mu \mathrm{g} / \mathrm{mL})$ was mixed with $1 \mathrm{~mL}$ nitroblue tetrazolium solution $(156 \mu \mathrm{M}$ in $0.1 \mathrm{M}$ phosphate buffer, $\mathrm{pH}$ 7.4) and $1 \mathrm{~mL}$ nicotinamide adenine dinucleotide (NADH) solution (468 $\mu \mathrm{M}$ in $0.1 \mathrm{M}$ phosphate buffer, $\mathrm{pH}$ 7.4). The reaction started by adding $100 \mu \mathrm{L}$ of phenazine methosulphate (PMS) solution $(60 \mu \mathrm{M}$ in $0.1 \mathrm{M}$ phosphate buffer, $\mathrm{pH}$ 7.4). The mixture was incubated at room temperature for $5 \mathrm{~min}$, and the absorbance was measured spectrophotometrically at $560 \mathrm{~nm}$ (Jenway, UK) against the blank sample (phosphate buffer). Ascorbic acid was used as positive control. The inhibition percentage of superoxide anion generation was calculated using the following formula: Superoxide anion scavenging ability $(\%)=[(A 0-A 1) / A 0] \times 100$, where $A 0$ is the absorbance of the negative control (consisting of all the reaction agents except the extract) and A1 is the absorbance of reaction mixture or standard. For both the extract and ascorbic acid, $\mathrm{IC}_{50}$ values were determined.

Reducing power

The reducing power of the samples was determined according to the method described by Oyaizu [12]. One milliliter of the test samples $(62.5,125,250$, 500 and $1000 \mu \mathrm{g} / \mathrm{mL}$ ) was mixed with $2.5 \mathrm{~mL}$ of phosphate buffer $(2.5 \mathrm{~mL}, 0.2 \mathrm{~mol} / \mathrm{L}, \mathrm{pH} 6.6)$ and potassium ferricyanide $(2.5 \mathrm{~mL}, 1 \%)$. The mixtures were incubated at $50^{\circ} \mathrm{C}$ for $20 \mathrm{~min}$. Then, $2.5 \mathrm{~mL}$ of $10 \%$ trichloroacetic acid was added to the mixture and centrifuged (HermLe, Wehingen, Germany). Finally, the upper layer was mixed with distilled water $(2.5 \mathrm{~mL})$ and ferric chloride $(0.5 \mathrm{~mL}$ of $0.1 \%)$. The absorbance of the solution was measured spectrophotometrically at $700 \mathrm{~nm}$ (Bibby Scientific Limited, Stone, UK). The blank was prepared with all the reaction agents without the extract. Higher absorbance of the reaction mixture 
indicated that the reducing power was increased. Ascorbic acid was used as a positive control.

Determining the antimicrobial activity

Microorganisms and media

The following bacteria were used as test organisms: Staphylococcus aureus (ATCC 25923), Bacillus subtilis (ATCC 6633), Bacillus cereus (ATCC 10987), Escherichia coli (ATCC 25922) and Proteus mirabilis (ATCC 12453). The bacterial cultures were maintained on Müller-Hinton agar substrates (Torlak, Belgrade). The fungi used as test organisms were: Aspergillus niger (ATCC 16888), Candida albicans (ATCC 10259), Penicillium italicum (ATCC 10454), Mucor mucedo (ATCC 20094), Trichoderma viride (ATCC 13233). All the bacteria and fungi used were obtained from the American Type Culture Collection (ATCC). The fungal cultures were maintained on potato dextrose (PD) agar, except for Candida albicans which was maintained on Sabourad dextrose agar (Torlak, Belgrade). All of the cultures were stored at $4{ }^{\circ} \mathrm{C}$ and subcultured every 15 days.

Bacterial inoculi were obtained from bacterial cultures incubated for $24 \mathrm{~h}$ at $37^{\circ} \mathrm{C}$ on MüllerHinton agar substrate and brought up by dilution according to the 0.5 McFarland standard to approximately $10^{8} \mathrm{CFU} / \mathrm{mL}$. The suspensions of fungal spores were prepared from fresh mature (3to 7-day-old) cultures growing at $30^{\circ} \mathrm{C}$ on a $\mathrm{PD}$ agar substrate. Spores were rinsed with sterile distilled water, used to determine the turbidity spectrophotometrically at $530 \mathrm{~nm}$, and then further diluted to approximately $10^{6} \mathrm{CFU} / \mathrm{mL}$ according to the procedure recommended by NCCLS [13].

Minimum inhibitory concentration (MIC)

The MIC value was determined using 96-well micro-titer plates (Spektar, Čačak, Serbia) by the broth microdilution method [14]. A series of extract dilutions with concentrations ranging from 40 to $0.004 \mathrm{mg} / \mathrm{mL}$ were used in the experiment against every microorganism tested. The starting solution of test samples was obtained by measuring off a certain quantity of sample and dissolving it in DMSO. Two-fold dilutions of test sample were prepared in Müller-Hinton broth for bacterial cultures and broth for fungal cultures. The MIC was determined with resazurin. Resazurin is an oxidation-reduction indicator used for the evaluation of microbial growth. It is a blue nonfluorescent dye that becomes pink and fluorescent when reduced to resorufin by oxidoreductases within viable cells. The boundary dilution without any changing color of resazurin was defined as the MIC for the tested microorganism at the given concentration. Streptomycin (for bacteria) and ketoconazole (for fungi) were used as a positive control. The solvent control test was performed to study an effect of $5 \%$ DMSO on the growth of microorganisms. All experiments were performed in triplicate.
Determining the cytotoxic activity

Cancer cell lines

Human epithelial carcinoma HeLa cells, human lung carcinoma A549 cells and human colon carcinoma LS174 cells were obtained from ATCC (Manassas, VA, USA). All cancer cell lines were cultured as a monolayer in the RPMI 1640 nutrient medium, with $10 \%$ FBS (inactivated at $56^{\circ} \mathrm{C}$ ), 3 $\mathrm{mM}$ of L-glutamine and antibiotics, at $37^{\circ} \mathrm{C}$ in humidified air atmosphere with $5 \% \quad \mathrm{CO}_{2} . \quad \mathrm{IC}_{50}$ values are expressed as the mean $\pm \mathrm{SD}$ (standard deviation) determined from the results of 3-4,5dimethylthiazol-2-yl-2,5-diphenyltetrazolium bromide (MTT) assay in two independent experiments.

In vitro cytotoxic assay

In vitro cytotoxic assay of the investigated extract was performed when the cells reached 70-80\% confluence. A stock solution $(50 \mathrm{mg} / \mathrm{mL})$ of the extract was dissolved in the corresponding medium to the required working concentrations. Neoplastic HeLa, A549 and LS174 cells (5000 cells per well) were seeded into 96 - well microtiter plates, and 24 $\mathrm{h}$ later, after cell adherence, 5 different, double diluted concentrations of investigated extract were added to the wells. Final concentrations of the extract were $12.5,25,50,100,200 \mu \mathrm{g} / \mathrm{mL}$ except for the control wells, where only nutrient medium was added. The cultures were incubated for the next $72 \mathrm{~h}$. The activity on cancer cell survival was determined $72 \mathrm{~h}$ after the addition of the extract, by the MTT test [15]. Briefly, $20 \mu \mathrm{L}$ of MTT solution (5 $\mathrm{mg} / \mathrm{mL}$ PBS) was added to each well and incubated for a further $4 \mathrm{~h}$ at $37^{\circ} \mathrm{C}$ in $5 \% \mathrm{CO}_{2}$ and humidified air. Subsequently, $100 \mu \mathrm{L}$ of $10 \%$ sodium dodecyl sulphate was added to solubilize the formazan crystals formed from MTT after the conversion by mitochondrial dehydrogenases of viable cells. Absorbances proportional to the number of viable cells were measured using a microplate reader (Multiskan EX, Thermo Scientific, Finland) at $570 \mathrm{~nm}$. Each experiment was performed in triplicate and independently repeated at least four times.

Determining the genotoxic and antimutagenic activities In vitro cytokinesis-block micronucleus (MN) assay Peripheral blood lymphocytes (PBLs) of healthy donors were used in determining the in vitro genotoxic and antimutagenic activities of five different concentrations of mushroom extract (12.5, $25,50,100$ and $200 \mu \mathrm{g} / \mathrm{mL}$ ). The experiments were in accordance with the guidelines of the World Medical Assembly (Declaration of Helsinki) and informed consent was obtained from all donors.

Whole heparinized blood $(0.5 \mathrm{~mL})$ was cultured in $5 \mathrm{~mL}$ of PB-MAX Karyotyping (Gibco by Life Technologies, USA), the complete medium for lymphocyte cultivation. Cell cultures were incubated at $37^{\circ} \mathrm{C}$ for $72 \mathrm{~h}$. The extract in five different concentrations and small volume $(0.1$ 
FARMACIA, 2019, Vol. 67, 1

$\mathrm{mL}$ ), separately or in combination with known mutagen mitomycin $\mathrm{C}$ (MMC, final concentration of $0.5 \mu \mathrm{g} / \mathrm{mL}$ ), were added to cell cultures $24 \mathrm{~h}$ after the beginning of incubation. After forty-four hours of incubation cytochalasin B (Sigma, St. Louis, MO, USA) was added to cultures, in the final concentration of $4 \mu \mathrm{g} / \mathrm{mL}$. Further, the cells were centrifuged and treated with cold $\left(4^{\circ} \mathrm{C}\right)$ hypotonic solution $(0.56 \% \mathrm{KCl})$ and fixed with methanol: glacial acetic acid $=3: 1$, three times. The slides were lamp dried and stained with $2 \%$ Giemsa (Alfapanon, Novi Sad, Serbia). The MN frequency was determined in 1000 binucleated $(\mathrm{BN})$ cells from each donor (3000 BN cells per concentration). To calculate the nuclear division index (NDI), 500 cells from each donor were scored. NDI were calculated using the formula NDI $=([1 \times \mathrm{x} 1]+[2$ $\mathrm{x}$ M2] $+[3 \mathrm{x}$ M3 $\left.]+\left[4 \mathrm{x} \mathrm{M}^{2}\right]\right) / \mathrm{N}$, where M1-M4 represented the number of cells with 1 to 4 nuclei and $\mathrm{N}$ was the total number of the cells scored [16]. Statistical analysis

Statistical analysis was performed using the EXCEL (version 2010) and SPSS (version 20) software packages. The $\mathrm{IC}_{50}$ values were calculated from the dose curves by software (CalcuSyn). To determine the statistical significance of the antioxidant and genotoxic activities Student's $t$-test was used. The relationship between the tested concentrations of the extract and both MN and NDI was determined by Pearson correlation coefficient. All values are expressed as mean $\pm \mathrm{SD}$. In all cases $p<0.05$ was considered statistically significant.

\section{Results and Discussion}

HPLC analysis

The content of the polyphenolic compounds in the acetone extract of $H$. repandum and retention times (tR) determined by HPLC analysis are shown in Table I.

Table I

The polyphenolic compounds of Hydnum repandum acetone extract

\begin{tabular}{|l|c|c|}
\hline $\begin{array}{c}\text { Polyphenolic } \\
\text { compounds }\end{array}$ & tR (min) & $\begin{array}{c}\text { H. repandum } \\
(\mu \mathrm{g} / \mathrm{g})\end{array}$ \\
\hline Phenolic acids & \multicolumn{3}{|c|}{} \\
\hline gallic acid & 8.252 & $1.30 \pm 0.10$ \\
\hline$p$-coumaric acid & 13.249 & $8.30 \pm 0.70$ \\
\hline chlorogenic acid & 16.277 & $1.81 \pm 0.03$ \\
\hline caffeic acid & 17.329 & n.d. \\
\hline syringic acid & 17.656 & $2.15 \pm 0.09$ \\
\hline ferulic acid & 20.601 & $12.10 \pm 0.20$ \\
\hline Flavonoids & 15.855 & $4.95 \pm 0.06$ \\
\hline catechin & 18.471 & $3.38 \pm 0.02$ \\
\hline rutin & 24.901 & $22.50 \pm 0.10$ \\
\hline quercetin
\end{tabular}

Five phenolic acids (gallic, $p$-coumaric, chlorogenic, syringic and ferulic acid) and three flavonoids (catechin, rutin and quercetin) were found in the extract. Caffeic acid was under the limit of detection in the extract.

The chromatograms for standards and acetone extract are represented in Figure 1 and 2.

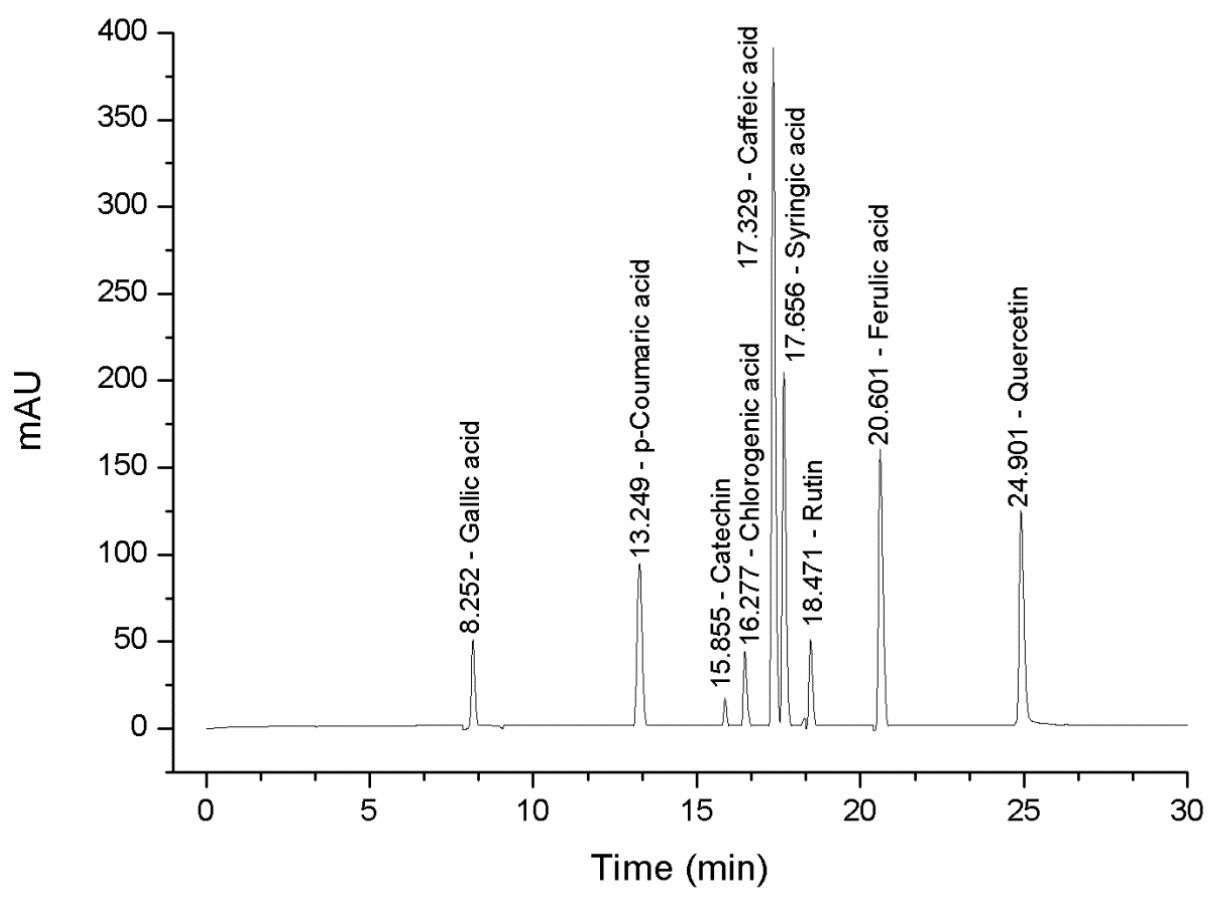

Figure 1.

HPLC chromatogram for mushroom standards of selected polyphenolic compounds 


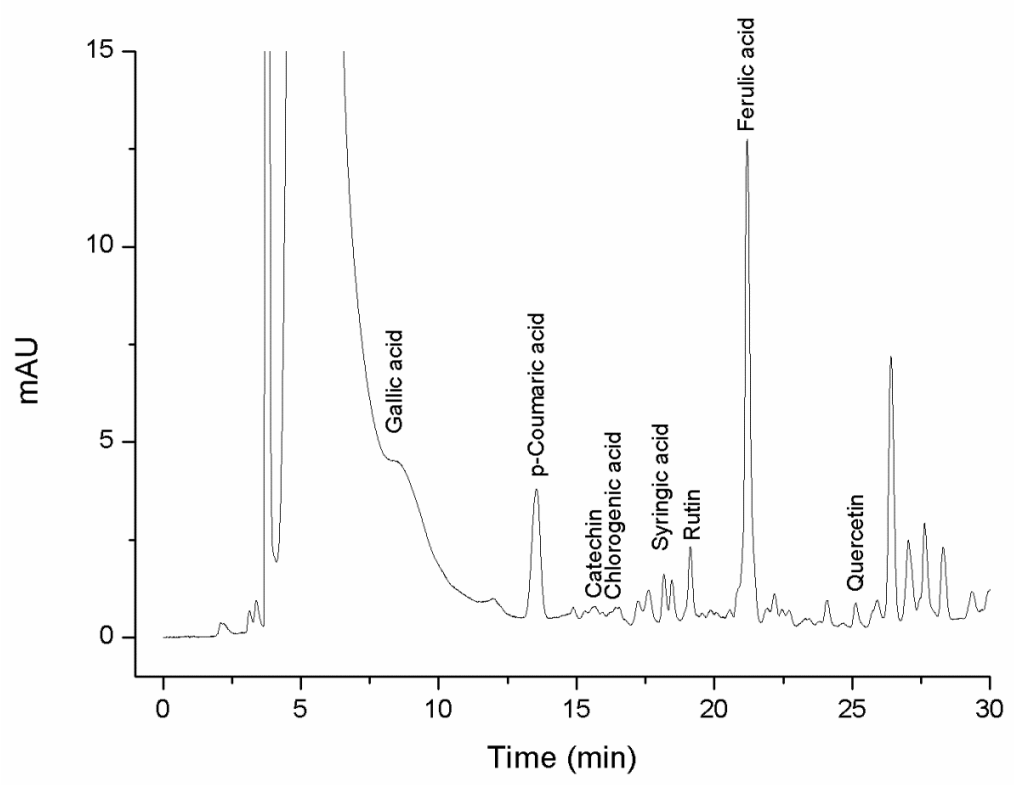

Figure 2.

HPLC chromatogram of the acetone extract of Hydnum repandum

\section{Antioxidant activity}

Free radical scavenging and reducing power of the studied extract are presented in Tables 2 and 3. The $\mathrm{IC}_{50}$ values for DPPH radicals and superoxide anion radicals scavenging activity were 35.41 and 19.28 $\mu \mathrm{g} / \mathrm{mL}$, respectively (Table 2 ). As shown in Table

3 , the reducing power of the extract was concentration dependent. The measured values of absorbance for reducing power varied from 0.032 to 0.081 . In various antioxidant activities there was a statistically significant difference between the extract and control samples $(\mathrm{p}<0.05)$.

Table II Free radical scavenging activity of acetone extract obtained from Hydnum repandum

\begin{tabular}{|c|c|c|}
\hline Samples & $\begin{array}{c}\text { DPPH radical } \\
\text { scavenging } \\
\mathrm{IC}_{50}(\mu \mathrm{g} / \mathrm{mL})\end{array}$ & $\begin{array}{c}\text { Superoxide anion } \\
\text { scavenging } \\
\mathrm{IC}_{50}(\mu \mathrm{g} / \mathrm{mL})\end{array}$ \\
\hline H. repandum & $35.41 \pm 1.05$ & $19.28 \pm 1.01$ \\
\hline $\begin{array}{c}\text { Positive control } \\
\text { (ascorbic acid) }\end{array}$ & $6.42 \pm 0.18$ & $115.61 \pm 1.16$ \\
\hline
\end{tabular}

Reducing power of acetone extract obtained from Hydnum repandum

\begin{tabular}{|c|c|c|c|}
\hline Samples & $2000 \mu \mathrm{g} / \mathrm{mL}$ & $1000 \mu \mathrm{g} / \mathrm{mL}$ & $500 \mu \mathrm{g} / \mathrm{mL}$ \\
\hline H. repandum & $0.081 \pm 0.031$ & $0.044 \pm 0.025$ & $0.032 \pm 0.008$ \\
\hline $\begin{array}{c}\text { Positive control } \\
\text { (ascorbic acid) }\end{array}$ & $3.862 \pm 0.992$ & $2.113 \pm 0.032$ & $1.654 \pm 0.021$ \\
\hline
\end{tabular}

Antimicrobial activity

The antimicrobial activity of the tested extract against the test microorganisms is shown in Table 4. The extract from $H$. repandum acted on all the tested microorganisms. The most sensitive among the microorganisms was $B$. cereus $(\mathrm{MIC}=0.009$ $\mathrm{mg} / \mathrm{mL})$. The antimicrobial activity was compared with the standard antibiotics, streptomycin for bacteria or ketoconazole for fungi. The results showed that streptomycin had similar antibacterial activity, while ketoconazole was more active than the tested mushroom.

Table IV

Minimum inhibitory concentration (MIC) of acetone extract obtained from Hydnum repandum

\begin{tabular}{|l|c|c|c|}
\hline Microorganisms & $\begin{array}{c}\text { H. repandum } \\
(\mathrm{mg} / \mathrm{mL})\end{array}$ & $\begin{array}{c}\mathrm{S} \\
(\mathrm{mg} / \mathrm{mL})\end{array}$ & $\begin{array}{c}\mathrm{K} \\
(\mathrm{mg} / \mathrm{mL})\end{array}$ \\
\hline Bacteria \\
\hline Bacillus cereus & 0.019 & 0.031 & - \\
\hline Bacillus subtilis & 0.009 & 0.016 & - \\
\hline Escherichia coli & 0.039 & 0.016 & - \\
\hline Proteus mirabilis & 0.078 & 0.062 & - \\
\hline Staphylococcus aureus & 0.039 & 0.062 & - \\
\hline
\end{tabular}


FARMACIA, 2019, Vol. 67, 1

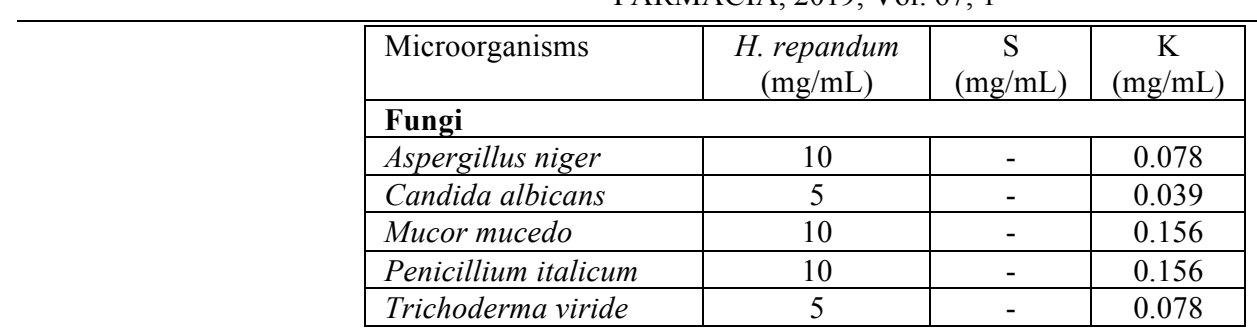

Antibiotics: $\mathrm{K}$ - ketoconazole, $\mathrm{S}$ - streptomycin

\section{Cytotoxic activity}

The results obtained for the anticancer activity of the extract are shown in Table 5. The $\mathrm{IC}_{50}$ against HeLa, A549 and LS174 cancer cell lines was $116.42,150.74$ and $158.33 \mu \mathrm{g} / \mathrm{mL}$, respectively. In all tested cell lines, the extract had weaker inhibiting activity than cis-dichlorodiammineplatinum (cis-DDP), as a positive control.

Table V

Growth inhibitory effect of acetone extract obtained from Hydnum repandum on HeLa, A549, LS174 and MRC5

\begin{tabular}{|c|c|c|}
\hline \multirow{2}{*}{ Cell lines } & $\begin{array}{c}\text { H. repandum extract } \\
(\mathrm{mg} / \mathrm{mL})\end{array}$ & $\begin{array}{c}\mathrm{IC}_{50} \\
(\mu \mathrm{g} / \mathrm{mL})\end{array}$ \\
\cline { 2 - 4 } & \multicolumn{2}{|c|}{ Cis-DDP } \\
\hline HeLa & $116.42 \pm 2.53$ & $0.86 \pm 0.33$ \\
\hline A549 & $150.74 \pm 1.64$ & $4.91 \pm 0.42$ \\
\hline LS174 & $158.33 \pm 0.81$ & $3.18 \pm 0.29$ \\
\hline MRC5 & $>200$ & $13.21 \pm 0.37$ \\
\hline
\end{tabular}
cell survival

CIS-DDP $=$ cis-dichlorodiammineplatinum

\section{Genotoxic and antimutagenic activities}

The activities of different concentrations of the mushroom extract on MN frequencies, NDI values and their distributions in both separate and against MMC treatments are shown in Table 6. The extract increased the MN frequency, but significantly only at higher concentrations $(\mathrm{p}<0.05)$. Pearson correlation coefficient showed that the extract increased $\mathrm{MN}$ frequency in a dose dependent manner $(r=0.837, p<0.01)$. NDI values decreased with the increase of extract concentration, but significantly only at the highest concentration, in comparison to untreated PBLs. In combined treatment, the extract of the MMC-increased MN frequencies slowly decreased, but significantly only at highest concentration. Correlations between the extract concentrations and $\mathrm{MN}$ frequencies was negative and significant $(\mathrm{r}=-0.730, \mathrm{p}<0.001)$. All tested concentrations of the extract decreased the MMC-induced NDI values dose dependently ( $\mathrm{r}$ $=-0.522, \mathrm{p}<0.05)$ and with statistical significance only at the highest tested concentration $(\mathrm{p}<0.05)$. The analysis of MN distribution per $3000 \mathrm{BN}$ cells per treatment revealed that in both separate and against MMC treatments the most $\mathrm{BN}$ cells were with $1 \mathrm{MN}$, while cells with 2 or more $\mathrm{MN}$ were considerably less present.

Over the last few decades, the biological activities of the various mushrooms have been investigated for their protective activity on human health. It is well known that solvents play an important role in the extraction of important bioactive substances. Acetone proved to be the most efficient solvent for the extraction of bioactive secondary metabolites [17]. Therefore, in this study acetone was chosen as a solvent for extracting the bioactive substances from $H$. repandum.

The chemical composition of the extract determines its biological activity which is reflected in stronger or weaker antioxidant, antimicrobial, genotoxic, cytotoxic or antiproliferative activity [18]. The content of polyphenolic compounds was positively correlated with the biological activities of mushroom extracts. However, the total phenolic acids and flavonoids contents are not as well as important for the exhibited activity, as the concentration of individual polyphenolic compounds [19].

We analyzed the presence of nine secondary metabolites. The main phenolic acid was ferulic, and beside that, the extract contained $p$ coumaric, chlorogenic, gallic and syringic acids. Quercetin was the major flavonoid, but both catechin and rutin were also present in high quantity too. Similarly, Sułkowska-Ziaja et al. [6] reported the presence of gallic and syringic acids in $H$. repandum mushroom.

It is known that ferulic acid can modulate molecular mechanisms involved in a multitude of biological activities. Previously published results showed that ferulic acid has cytotoxic activity against human prostate cancer cell lines PC-3 and LNCaP [20], and TT medullary thyroid cancer cell line [21]. 


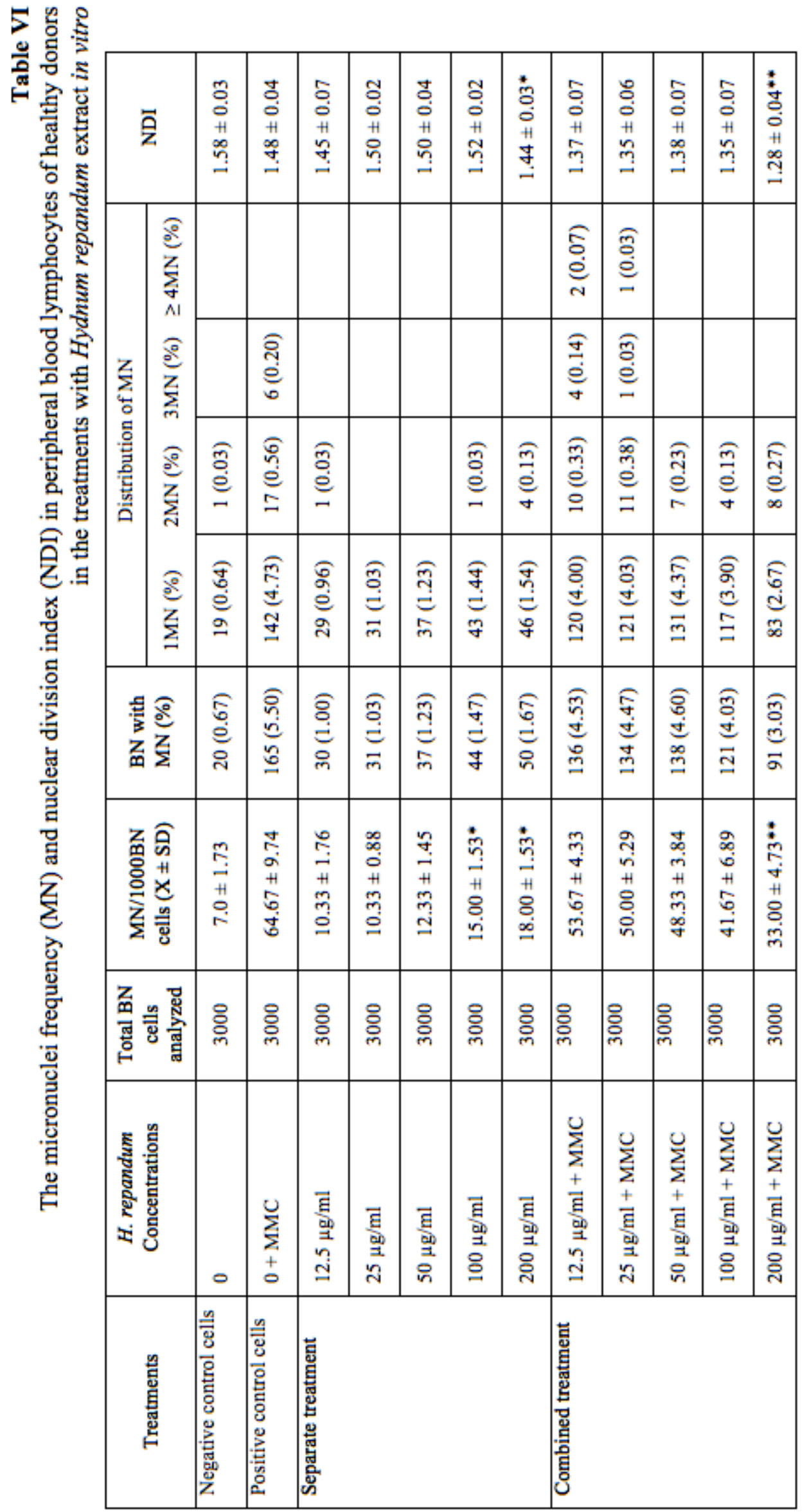

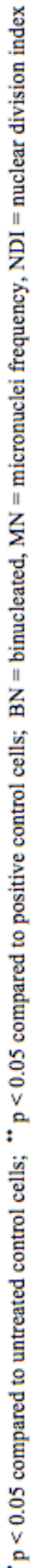


FARMACIA, 2019, Vol. 67, 1

Similarly, Jaganathan et al. [22], studying the effect of $p$-coumaric acid concluded that this acid has a good inhibitory activity against two colon cancer cells (HCT 15 and HT 29).

Srivastava et al. [23] came to the same conclusion, studying the inhibitory activities of flavonoids, especially quercetin against leukaemia and breast cancer.

Our results on the antioxidant activity against various oxidative systems in vitro indicate that the extract showed very strong free radical scavenging activity, while the reducing power was less emphasized. This activity of the extract was based on its ability to form the non-radical form of DPPH-H as well as on its ability to destroy the superoxide radical produced from the PMS/NADH reaction which is a weak oxidative agent but induces the formation of highly reactive free radicals.

The antioxidant activity of $H$. repandum extract was also examined by Sułkowska-Ziaja et al. [6], but these authors used different solvent agents. Different extraction solvents, according to their polarity, may extract various compounds involved in the antioxidant activity. This means that synergistic activities may occur between these constituents leading to the pronounced antioxidant activity of extract [24]. The intensity of the antimicrobial activity of $H$. repandum acetone extract in our study depended on the used concentration of the extract and the tested microorganisms. We observed slightly higher activity against Grampositive than Gram-negative bacteria strains, while the tested mushroom extract, in the same concentrations, showed a stronger antibacterial than antifungal activity. These results are comparable with previous results regarding the antimicrobial and antifungal activity of mushrooms. For example, Kosanić et al. [9] proved that bacteria are more sensitive to herbal extracts compared to the fungi. The reason for different sensitivity between the fungi and bacteria can be found in different transparencies of the cell wall. Similar to our results, Ozen et al. [7] demonstrated that the highest antimicrobial activity of $H$. repandum methanolic extract was expressed against Pseudomonas aeruginosa (ATCC 27853) and Escherichia coli (W3110), followed by Staphylococcus aureus (ATCC 6535), Bacillus cereus (ATCC 7064) and only one fungal species of Candida albicans (ATCC 10231). The probable mechanisms of the antimicrobial action of the tested mushroom are the inhibition of cell wall synthesis, protein synthesis, or nucleid acid synthesis, but less effective compared to the classical antibiotics. $P$ coumaric and ferulic acids extracted from mushrooms exhibited antimicrobial activity against Escherichia coli and Proteus mirabilis [25].

The tested extract expressed moderate cytotoxic activity on the used cancer cells, among which HeLa were the most sensitive. There has been no available information about the cytotoxic potential of $H$. repandum species, but some researchers examined the cytotoxic potential of other mushrooms. For example, Kosanić et al. [9] showed that methanolic extracts from Lactarius deliciosus and Macrolepiota procera exhibited significant cytotoxic activities. Also, edible mushrooms, Agaricus bisporus, Lentinula edodes and Pleurotus ostreatus, extracted by different polar and non-polar solvents, inhibited the proliferation of human liver carcinoma (HepG2), the human colon epithelial carcinoma (HCT116) and the human cervical cancer cells (HeLa) [26].

Edible mushrooms are regarded as non-toxic and safe, but recent investigations reported that some of them cause DNA damages [27]. Numerous studies showed that the CBMN assay is a valid test for detection of genomic damage caused both in vitro $[28,29]$ and in vivo [30,31].

Our results of CBMN assay showed that the extract was genotoxic in higher tested concentrations. In treatment against MMC all tested concentrations of the extract showed protective activity. Namely, the acetone extract lowered the MMC-induced MN frequencies and NDI values dose dependently, but significantly only in the highest tested concentration. The analysis of MN distribution showed that the percentage of cells with $1 \mathrm{MN}$ and 2 MN increased for about two and four times (0.64 vs. $1.54 \%$ and 0.03 vs. $0.13 \%$ ) in the treatment with the highest tested concentration of the extract compared to the negative control (without treatment). In treatment with MMC the percentage of cells with $2 \mathrm{MN}$ decreased for about two times after the highest tested concentration of the extract compared to the positive control (0.56vs. $0.27 \%)$, while cells with 3 and $4 \mathrm{MN}$ were only seen in the positive control (MMC alone) and in the treatment with lower concentrations of the extract (12.5 and $25 \mu \mathrm{g} / \mathrm{mL}$ ).

To our knowledge, there are no available results about the genotoxic activity of $H$. repandum, but some authors have investigated this activity on other mushrooms. Thus, it has been shown that the aqueous extract of Lentinula edodes has moderate genotoxic activity on the epidermal cells of human larynx carcinoma (HEp-2), and that the highest concentration of the extract shows antigenotoxic activity against methyl methanesulfonate [32]. Also, Knežević et al. [33] and Živković et al. [34] showed that the ethanolic extract of Agaricus brasiliensis had high antigenotoxic activity against $\mathrm{H}_{2} \mathrm{O}_{2}$ induced DNA damage in human PBLs applying 
FARMACIA, 2019, Vol. 67, 1

comet test. They concluded that the antigenotoxic activity of mushrooms could be attributed to their scavenging properties and antioxidant mechanisms.

Based on our results in the treatment with MMC, we can conclude that the extract did not accomplish the antimutagenic activity by inhibition of the effect of MMC, but that the cells which collected a large amount of genetic damage were transferred into natural processes of apoptosis. This is indicated by the reduction of both MN frequency and NDI values in all tested concentrations of the extract, especially in the highest. The proapoptotic effect of the extract can be attributed to the rich polyphenolic composition of mushroom, especially ferulic acid and quercetin. Recently, Srivastava et al. [23] came to the similar conclusions.

\section{Conclusion}

This study showed that the acetone extract from $H$. repandum showed different biological activities such as strong antioxidant activity after DPPH solution, antimicrobial activity depending on the concentration of the extract and tested microorganism, moderate cytotoxic activity on HeLa, A549 and LS174 cancer lines, among which HeLa cells were the most sensitive ones, genotoxic activity in cultured human healthy PBLs depending on the concentration of the extract, and protective activity against MMC. These activities are in correlation with the rich composition of polyphenols, especially ferulic acid and quercetin which were the most common in the extract. The extraction of polyphenolic compounds and use in a diet can be of great importance for the prevention and treatment of various pathological conditions.

\section{Acknowledgements}

Our work was supported by the Ministry of Education, Science and Technological Development of the Republic of Serbia (Projects No. III41010; 173032).

\section{References}

1. Nallathamby N, Phan C, Seow SL, Baskaran A, Lakshmanan H, Malek SNA, Sabaratnam V, A status review of the bioactive activities of tiger milk mushroom Lignosus rhinocerotis (Cooke) Ryvarden. Front Pharmacol., 2018; 8: 1-15.

2. Kubota A, Kobayashi M, Sarashina S, Takeno R, Okamoto K, Narumi K, Furugen A, Suzuki Y, Takahashi N, Isekia K, Reishi mushroom Ganoderma lucidum Modulates IgA production and alpha defensin expression in the rat small intestine. $J$ Ethnopharmacol., 2018; 214: 240-243.
3. Rahi DK, Malik D, Diversity of mushrooms and their metabolites of nutraceutical and therapeutic significance. J Mycol., 2016; 2016: 1-18.

4. Sánchez S, Reactive oxygen species and antioxidant properties from mushrooms. Synth Syst Biotechnol., 2017; 2: 13-22.

5. Uzelac B, Fungi of Serbia and the Western Balkans, BGV Logik, Belgrade, 2009.

6. Sułkowska-Ziaja K, Muszynska B, Szewczyk A, Antioxidant components of selected indigenous edible mushrooms of the obsolete order Aphyllophorales. Rev Iberoam Micol., 2015; 32: 99-102.

7. Ozen T, Darcan C, Aktop O, Turkekul I, Screening of antioxidant, antimicrobial activities and chemical contents of edible mushrooms wildly grown in the black sea region of Turkey. Comb Chem High Throughput Screen., 2011; 14: 72-84.

8. Takahashi A, Endo T, Nozoe S Repandiol, a new cytotoxic diepoxide from the mushrooms Hydnum repandum and $H$. repandum var. album. Chem Pharm Bull., 1992; 40: 3181-3184.

9. Kosanić M, Ranković B, Rančić A, Stanojković T, Evaluation of metal concentration and antioxidant, antimicrobial, and anticancer potentials of two edible mushrooms Lactarius deliciosus and Macrolepiota procera. J Food Drug Anal., 2016; 24: 477-484.

10. Dorman HJ, Bachmayer O, Kosar M, Hiltunen R, Antioxidant properties of aqueous extracts from selected Lamiaceae species grown in Turkey. J Agric Food Chem., 2004; 52: 762-770.

11. Nishimiki M, Rao NA, Yagi K, The occurrence of super-oxide anion in the reaction of reduced phenazine methosulfate and molecular oxygen. Biochem Biophys Res Commun., 1972; 46: 849-853.

12. Oyaizu M, Studies on products of browning reactions: Antioxidative activities of product of browning reaction prepared from glucosamine. Japan $J$ Nutrition, 1986; 44: 307-315.

13. National Committee for Clinical Laboratory Standards (NCCLS). Reference method for broth dilution antifungal susceptibility testing of conidium-forming filamentous fungi. Proposed Standard M38-P, NCCLS, Wayne, PA, USA, 1998.

14. Sarker SD, Nahar L, Kumarasamy Y, Microtiter platebased antibacterial assay incorporating resazurin as an indicator of cell growth, and its application in the in vitro antibacterial screening of phytochemicals. Methods, 2007; 42: 321-324.

15. Mosmann T, Rapid colorimetric assay for cellular growth and survival: application to proliferation and cytotoxicity assays. J Immunol Methods, 1983; 65: 5563.

16. Fenech $\mathrm{M}$, The in vitro micronucleus technique. Mutat Res., 2000; 455: 81-95.

17. Tan SP, Parks SE, Stathopoulos CE, Roach PD, Extraction of flavonoids from bitter melon. Food Nutr Sci., 2014; 5: 458-465.

18. Teklit GA, Chemical composition and nutritional value of the most widely used mushrooms cultivated in Mekelle Tigray Ethiopia. J Nutr Food Sci., 2015; 5: 1-3.

19. Palacios I, Lozano M, Moro C, D'Arrigo M, Rostagno MA, Martínez JA, García-Lafuente A, Guillamón E, Villares A, Antioxidant properties of phenolic 
compounds occurring in edible mushrooms. Food Chem., 2011; 128: 674-678.

20. Eroğlu C, Seçme M, Bağcı G, Dodurga Y, Assessment of the anticancer mechanism of ferulic acid via cell cycle and apoptotic pathways in human prostate cancer cell lines. Tumor Biol., 2015; 36: 9437-9446.

21. Dodurga Y, Eroglu C, Secme M, Elmas L, Avci CB, Satiroglu-Tufan NL, Anti-proliferative and antiinvasive effects of ferulic acid in TT medullary thyroid cancer cells interacting with URG4/URGCP. Tumor Biol., 2016; 37: 1933-1940.

22. Jaganathan SK, Supriyanto E, Mandal M, Events associated with apoptotic effect of $p$-coumaric acid in HCT-15 colon cancer cells. World J Gastroenterol., 2013; 19: 7726-7734.

23. Srivastava $\mathrm{S}$, Somasagara RR, Hegde M, Nishana M, Tadi SK, Srivastava M, Choudhary B, Raghavan SC, Quercetin, a Natural Flavonoid Interacts with DNA, Arrests Cell Cycle and Causes Tumor Regression by Activating Mitochondrial Pathway of Apoptosis. Sci Rep., 2016; 6: 24049.

24. Ngo TV, Scarlett CJ, Bowyer MC, Ngo PD, Van VQ, Impact of different extraction solvents on bioactive compounds and antioxidant capacity from the root of Salacia chinensis L. J Food Quality., 2017; 2017: 1-8.

25. Mitani T, Ota K, Inaba N, Kishida K, Koyama HA, Antimicrobial activity of the phenolic compounds of Prunus mume against Enterobacteria. Biol Pharm Bull., 2018; 41: 208-212.

26. Younis A, Stewart J, Wu FS, Shikh H, Hassan F, Elaasser M, Cytotoxic activity of edible mushrooms extracts against tumor cell lines. Int J Sci Tech., 2014; 3: $736-749$.
27. Jo WS, Hossain MA, Park SC, Toxicological profiles of poisonous, edible, and medicinal mushrooms. Mycobiology, 2014; 42: 215-220.

28. Fenech M, Cytokinesis-block micronucleus cytome assay. Nat Protoc., 2007; 2: 1084-1104.

29. Marques ES, Tsuboy MSF, Carvalho JCT, Rosa PCP, Perazzo FF, GaivÃ£o IOM, Maistro EL, First cytotoxic, genotoxic, and antigenotoxic assessment of Euterpe oleracea fruit oil (Açaí) in cultured human cells. Genet Mol Res., 2017; 16(3): 1-11.

30. Costa S, Ceppi M, Costa C, Silva S, Pereira C, Laffon B, Bonassi B, Teixeira JP, The cytokinesis-block micronucleus (CBMN) assay in human populations exposed to styrene: A systematic review and metaanalysis. Mutat Res., 2016; 770: 92-105.

31. Grujičić D, Radović M, Arsenijević S, MiloševićDjordjević O, Cytogenetic biomarkers in detection of genotoxic effects of gestagens in peripheral blood lymphocytes in vitro and in vivo. Eur J Med Genet., 2016; 59: 624-633.

32. Miyaji CK, Jordão BQ, Ribeiro LR, Eira AF, Cólus IMS, Genotoxicity and antigenotoxicity assessment of shiitake (Lentinula edodes (Berkeley) Pegler) using the Comet assay. Genet Mol Biol., 2004; 27: 108-114.

33. Knežević A, Živković L, Stajić M, Vukojević J, Milovanović I, Spremo-Potparević B, Antigenotoxic effect of Trametes spp. extracts against DNA damage on human peripheral white blood cells. Sci World J., 2015; 2015: 1-10

34. Živkovićm L, Borozan S, Čabarkapa A, Topalović D, Ciptasari U, Bajić V, Spremo-Potparević B, Antigenotoxic properties of Agaricus blazei against hydrogen peroxide in human peripheral blood cells. Oxid Med Cell Longev., 2017; 2017: 1-9. 